\title{
Pengaruh Efektivitas Penggunaan SIA, Pelatihan SIA, dan LOC Internal Pada Kinerja Karyawan LPD Kota Denpasar
}

\author{
Ni Made Sri Pawitri ${ }^{1}$ \\ Made Yenni Latrini ${ }^{2}$ \\ ${ }^{1,2}$ Fakultas EkonomidanBisnisUniversitasUdayana (Unud), Bali, Indonesia \\ e-mail: pawitrisri@gmail.com
}

\begin{abstract}
ABSTRAK
Penentuan sampel dalam penelitian ini menggunakan teknik sampling dengan metode non probability sampling, khususnyametodepurposive sampling. Penelitian ini dilakukan pada seluruh LPD di Kota Denpasar. Jumlah sampel yang diambil sebanyak 35 LPD dengan jumlah 105 amatan. Pengumpulan data dilakukan dengan instrumen kuesioner. Hasil dari kuesioner ini diukur menggunakan skala likert. Teknikanalisis data yang digunakanadalahanalisisregresi linier berganda.Berdasarkan hasil penelitian, diketahui bahwa variabel efektivitas penggunaan SIA, pelatihan SIA, dan LOC internal berpengaruh positif terhadap kinerja karyawan LPD di Kota Denpasar. Hal ini menunjukkan bahwa penggunaan SIA yang semakin efektif, rutin dalam melakukan pelatihan disertai dengan keyakinan dalam individu pengguna akan memberikan kemudahan dan manfaat bagi karyawan yang berpengaruh dalam peningkatan kinerja karyawan LPD di Kota Denpasar. Kata kunci: Efektivitas penggunaan SIA, pelatihan SIA, LOC Internal, kinerja karyawan.
\end{abstract}

\begin{abstract}
Determination of the sample in this study using a sampling technique with nonprobability sampling method, especially the purposive sampling method. This research was conducted on all LPDs in Denpasar City. The number of samples taken were 35 LPDs with 105 observations. Data collection is done by questionnaire instrument. The results of this questionnaire were measured using a Likert scale. The data analysis technique used is multiple linear regression analysis. Based on the results of the study, it is known that the effectiveness variables of the use of SIA, SIA training, and internal LOC have a positive effect on the performance of LPD employees in Denpasar City. This shows that the use of SIA that is more effective, routine in conducting training accompanied by confidence in individual users will provide convenience and benefits for employees who have an influence on improving the performance of LPD employees in Denpasar City.

Keywords: Effectiveness of the use of SIA, SIA training, Internal LOC, employee performance.
\end{abstract}

\section{PENDAHULUAN}

Perkembangan globalisasi yang terjadi hampir di seluruh belahan negara di dunia mengakibatkan tidak ada batasan untuk memperoleh informasi. Globalisasi memudahkan manusia untuk memperoleh informasi karena didukung oleh teknologi. Informasi adalah suatu kumpulan data yang diorganisasi yang dapat mendukung ketepatan pengambilan keputusan (Bodnar dan Hopwood, 2006: 3). 
Ni Made Sri Pawitri dan Made Yenni Latrini. Pengaruh ...

Dengan demikian informasi yang berbasis teknologi merupakan suatu kebutuhan bagi organisasi, salah satunya organisasi bisnis atau perusahaan. Pernyataan tersebut didukung oleh Sari (2009) yang menyatakan bahwa penggunaan teknologi informasi dalam menunjang sistem informasi membawa pengaruh terhadap hampir semua aspek dalam pengelolaan bisnis, sehingga akan lebih memajukan pengelolaan sumber daya dalam menghadapi persaingan antar organisasi bisnis. Persaingan yang ketat akan mendorong setiap perusahaan untuk menerapkan teknologi sistem informasi yang akan mendukung kegiatan operasional perusahaan secara efektif, efisien dan terkendali dan mencapai keunggulan yang kompetitif (Novia dan Juliarsa, 2017).

Mencapai suatu keunggulan perusahaan diperlukan peran dari seluruh perangkat perusahaan terutama sumber daya manusianya. Sumber Daya Manusia (SDM) yang mampu mengoperasikan sistem informasi dengan tepat akan mencapai produktivitas organisasi. Karyawan sebagai pemeran utama dalam penggerak perusahaan,perlu mendapatkan pengembangan kemampuan dan keterampilannya untuk bekerja lebih efektif lagi salah satunya yaitu dengan pelatihan kerja untuk meningkatkan kinerja (Engetou, 2017), sedangkan menurut Edison dkk., (2017: 203), kinerja adalah hasil dari suatu proses yang mengacu dan diukur selama periode waktu tertentu berdasarkan ketentuan atau kesepakatan yang telah ditetapkan sebelumnya. Sehingga dapat dikatakan bahwa kinerja karyawan memegang peranan penting dalam mewujudkan keberhasilan suatu perusahaan. 
Berdasarkan teori TAM (Technology Acceptance Model) yang ditemukan oleh Davis (2015) menjelaskan penggunaan suatu teknologi baru dalam individual atau organisasi, harus dipastikan mengenai penerimaan atau penolakan yang akan terjadi apabila teknologi tersebut digunakan. Model TAM ini memiliki persepsi kebermanfaatan (perceived usefulness) dan persepsi kemudahan (perceived ease of use) dimana akan mempengaruhi perilaku langsung pengguna dalam melaksanakan pekerjaannya (Lucyanda, 2010). Apabila persepsi pengguna lebih bermanfaat dan lebih mudah untuk digunakan, maka pengguna menerima adanya penggunaan teknologi baru dan berdampak langsung pada hasil kinerja yang meningkat.

Perkembangan teknologi informasi akan diiringi dengan perkembangan perusahaan juga, terutama pada bagian keuangan yang ditandai dengan kompleksitas transaksi pada perusahaan tersebut (Suhud dan Rohman, 2015). Pengelolaan transaksi keuangan tidak dipungkiri adalah suatu hal penting bagi perusahaan, karena penghasilan ataupun keuntungan yang dihasilkan merupakan tujuan dari perusahaan. Dengan demikian, semakin besar perusahaan, akan mengalami tingkat kompleksitas transaksi yang semakin besar yang artinya perlu suatu cara yang berbeda untuk melakukan pengelolaan dengan efektif dan efisien, salah satunya dengan menerapkan sistem informasi akuntansi.

Sistem Informasi Akuntansi (SIA) adalah kumpulan sumber daya seperti manusia dan peralatan yang dirancang untuk mengubah data keuangan dan data lainnya menjadi sebuah informasi (Bodnar dan Hopwood, 2006: 3). SIA melakukan tugas-tugas seperti input, proses, dan output untuk memenuhi tujuan 
Ni Made Sri Pawitri dan Made Yenni Latrini. Pengaruh ...

dari penggunaan SIA terpenuhi (Esmeray, 2016). Output atau hasil dari pengolahan informasi tersebut nantinya akan digunakan sebagai dasar untuk pengambilan keputusan oleh pihak-pihak yang berkepentingan atas informasi (AlEqab and Adel, 2013). Untuk itu pengembangan sistem informasi para pemakai menjadi fokus penting berkaitan dengan keefektifan sistem informasi akuntansi (Ayu dan Dharmadiaksa, 2017).

Tujuan dari pengembangan SIA dilakukan di organisasi adalah untuk menghasilkan informasi yang relevan, tepat waktu, dan akurat sehingga menimbulkan kepuasan pemakai sistem tersebut (Wahyu dan Suaryana, 2014). Selain menawarkan kemudahan penggunaan dan kecepatan waktu dalam penyelesaian pekerjaan, SIA juga akan bermanfaat untuk menambah nilai, seperti meningkatkan kualitas dan mengurangi biaya produk dan jasa, meningkatkan efisiensi, berbagi pengetahuan, meningkatkan struktur pengendalian internal, dan meningkatkan pengambilan keputusan (Romney and Steinbart, 2014: 11).

Suatu sistem dikatakan efektif, apabila mampu menghasilkan informasi yang berkualitas dan mampu membantu kinerja penggunanya, namun agar penggunaan SIA lebih bermanfaat, diperlukan pemahaman mengenai cara pengoperasian SIA dari segi pengguna SIA(Harash et al., 2014). Pelatihan khusus dibidangnya untuk karyawan yang kurang berpengalaman adalah hal yang penting bagi pengguna SIA (Dwijayanthi dan Dharmadiaksa, 2013). Selain meningkatkan pengalaman, pelatihan mampu meningkatkan pengetahuan, keterampilan, dan sikap yang baik untuk mengisi jabatan ataupun untuk meningkatkan kinerja yang lebih baik lagi disesuaikan dengan kebutuhan perusahaan. Selain itu, menurut 
Medina et al. (2014), pelatihan juga penting untuk mengembangkan keterampilan dimana akan memudahkan penggunaan SIA sehari-hari yang berdampak pada kepuasan dan mencapai kinerja yang lebih baik.

Berdasarkan penjelasan tersebut, karyawan harus bekerja keras untuk memperoleh hasil kinerja yang lebih baik dalam menggunakan sistem dengan meningkatkan pemahamannya tentang SIA. Tidak hanya dengan penerapan SIA dan pelatihan saja, namun kinerja karyawan dipengaruhi juga oleh faktor individual atau perilaku setiap karyawan, seperti locus of control karyawan (Rahman, 2009). Locus of control didefinisikan sebagai harapan umum dari hasil suatu peristiwa baik didalam maupun diluar dirinya atau sebagai suatu kontrol terhadap pemahaman pribadinya (Rotter, 1966). Locus of control terdiri dari dua jenis yaitu, locus of control eksternal dan locus of control internal.

Locus of control eksternal adalah sifat kepribadian yang cenderung menganggap suatu peristiwa terjadi dari luar kendalinya, seperti mengaitkan suatu peristiwa dengan kebetulan, keberuntungan, dan akibat pengaruh orang lain, sedangkan locus of control internal merupakan sifat kepribadian yang menganggap bahwa peristiwa yang terjadi tergantung pada dirinya sendiri (Praag et.al., 2014). Dari dua jenis locus of control tersebut, yang paling baik untuk dapat meningkatkan kinerja adalah locus of control Internal, karena menunjukkan motivasi yang lebih besar, menyukai hal-hal yang bersifat kompetitif, suka bekerja keras, merasa dikejar waktu dan ingin selalu berusaha lebih baik daripada kondisi sebelumnya, sehingga mengarah pada pencapaian prestasi yang lebih 
Ni Made Sri Pawitri dan Made Yenni Latrini. Pengaruh ...

tinggi. Dengan mencapai prestasi yang lebih tinggi, maka mampu meningkatkan kinerja karyawan tersebut.

Penelitian ini meneliti tentang kinerja karyawan dalam menerapkan SIA yang dilakukan di salah satu lembaga keuangan yang hanya ada di Provinsi Bali, yaitu Lembaga Perkreditan Desa (LPD). Alasan peneliti menggunakan tempat penelitian di LPD karena, LPD adalah lembaga keuangan yang berfokus untuk meningkatkan perekonomian desa menjadi lebih optimal melalui kredit dan simpanan dalam bentuk tabungan. Menurut (Nurjaya, 2011: 77), LPD jika dibandingkan dengan lembaga keuangan lain, memiliki sifat yang khas, karena dilihat dari dasar konstitusional, dasar hukum, asal-usul, tujuan, serta pola kerja sangat berbeda dengan lembaga keuangan lainnya dan dalam memilih anggota kepengurusan LPD lebih mengutamakan musyawarah dan mufakat bersama yang bernama paruman. Cara memilih kepengurusan seperti ini timbul keraguan kinerja LPD akan meningkat, namun aset LPD Provinsi Bali terus mengalami peningkatan, salah satunya adalah LPD di Kota Denpasar. LPD di Kota Denpasar juga memiliki perkembangan yang cukup baik yang ditandai dengan tidak adanya LPD yang dinyatakan bangkrut.

Seluruh LPD di Kota Denpasar dipilih karena telah menerapkan SIA, yaitu sebanyak 35 LPD dengan rata-rata total aset setiap tahunnya diatas Rp 1.000.000.000.000. Berdasarkan data Lembaga Pemberdayaan Lembaga Perkreditan Desa (LPLPD) tahun 2017, adalah sebagai berikut: 
Tabel 1.

Perkembangan Aset LPD di Kota Denpasar Tahun 2014-2017

\begin{tabular}{lcc}
\hline No & Tahun & Total Aset \\
\hline 1. & 2014 & $\mathrm{Rp} \mathrm{1.179.967.305.000}$ \\
2. & 2015 & $\mathrm{Rp} 1.383 .896 .375 .000$ \\
3. & 2016 & $\mathrm{Rp} 1.625 .610 .986 .000$ \\
4. & 2017 & $\mathrm{Rp} 1.932 .367 .745 .000$ \\
\hline \multicolumn{2}{l}{ Sumber: } & LP LPD Kota Denpasar, 2017
\end{tabular}

Berdasarkan Tabel 1 menunjukkan bahwa aset LPD di Kota Denpasar mengalami peningkatan setiap tahunnya. Ini menandakan bahwa partisipasi masyarakat dengan adanya LPD di Kota Denpasar semakin besar. Kepemilikan aset yang semakin besar diiringi dengan volume transaksi yang semakin kompleks, sehingga pengolahan data dengan SIA sangat dibutuhkan untuk mempermudah dan mendukung pekerjaan karyawan LPD. Seluruh LPD yang berada di Kota Denpasar telah menerapkan SIA sesuai dengan standar LPD dibawah pengawasan BKS-LPD (Badan Kerjasama LPD) dan telah menerapkan pelatihan bagi karyawan LPD di Kota Denpasar dengan didukung oleh perangkat operasional teknologi informasi yang canggih (Lampiran 2).

Penelitian yang dilakukan oleh (Urquia et al., 2011), menyatakan hasil penelitian bahwa penerapan SIA tidak meningkatkan kinerja, namun hasil penelitian Ariputra dan Suaryana (2018), menyatakan bahwa efektivitas sistem informasi akuntansi berpengaruh positif pada kinerja karyawan di kantor PLN Distribusi Bali. Menurut penelitian Husna dkk. (2017), menyatakan bahwa pelatihan berpengaruh negatif pada kinerja karyawan PT. Bank Riau KEPRI Kantor Pusat Pekanbaru, karena pelatihan yang diterima karyawan tidak sesuai dengan kebutuhan aktual karyawan, namun hasil penelitian Irma dan Dharmadiaksa(2015) menyatakan sebaliknya, yaitu pelatihan berpengaruh positif 
Ni Made Sri Pawitri dan Made Yenni Latrini. Pengaruh ...

pada kinerja karyawan dalam menerapkan SIA pada hotel berbintang tiga, empat, dan lima. Locus of control juga dinyatakan tidak berpengaruh pada kinerja karyawan (Mindarti, 2015), namun menurut Fitri (2016)locus of control berpengaruh pada kinerja karyawan.

Efektivitas merupakan suatu ukuran yang memberikan gambaran seberapa jauh target tercapai. Penggunaan teknologi di era digital seperti ini sangat membantu pekerjaan penggunanya untuk mencapai tujuan, karena teknologi menawarkan kemudahan, kecepatan, dan keakuratan dari output yang dihasilkan. Namun dalam penerapannya, beberapa kasus ditemukan bahwa teknologi sistem informasi tidak memberikan manfaat, akibat dari penggunaan yang tidak maksimal dari pengguna itu sendiri. Sehingga penerapan sistem tidak efektif bagi kinerja pengguna.

Menurut Teori TAM (Technology Acceptance Model) penerimaan penggunaan sistem informasi ditentukan oleh dua keyakinan, yaitu persepsi kebermanfaatan dan kemudahan penggunaan. Dengan demikian, persepsi atas teori ini adalah jika penggunaan sistem semakin bermanfaat dan mudah, maka pengguna akan mampu menggunakan sistem tersebut secara efektif sehingga mampu meningkatkan kinerja pengguna. Berdasarkan pernyataan tersebut, semakin efektif suatu sistem yang digunakan oleh pengguna, maka akan meningkatkan kinerja mereka (Imbiri, 2014).

Berdasarkan beberapa hasil penelitian terdahulu mendukung teori diatas seperti, Artanaya dan Gayatri(2016), menyatakan bahwa efektivitas SIA berpengaruh positif pada kinerja individual LPD. Fatmayoni dan Yadnyana 
(2017), juga mengatakan hal yang sama yaitu efektivitas SIA berpengaruh positif pada kinerja karyawan, kemudian Ariputra dan Suaryana (2018), yang menyatakan bahwa efektivitas SIA berpengaruh positif pada kinerja karyawan di kantor PLN Distribusi Bali. Sejalan dengan penelitian tersebut, Suryawan dan Suaryana (2018), juga menyatakan bahwa efektivitas SIA berpengaruh positif pada kinerja individual di LPD Kecamatan Sukawati.Berdasarkan penjelasan diatas, maka dapat dirumuskan hipotesis sebagai berikut:

$\mathrm{H}_{1}$ : Efektivitas Sistem Informasi Akuntansi (SIA) berpengaruh positif pada kinerja karyawan

Pelatihan adalah proses secara sistematis mengubah tingkah laku pegawai untuk mencapai tujuan organisasi. Pelatihan berkaitan dengan keahlian dan kemampuan pegawai yang berorientasi dalam pelaksanaan pekerjaan saat ini agar berhasil dalam melaksanakan pekerjaannya. Penggunaan sistem informasi bagi sebagian pengguna yang memiliki kemampuan yang berbeda tentu memerlukan pelatihan khusus di bidang itu untuk lebih memaksimalkan pemahaman mereka tentang cara kerja dari sebuah sistem, sehingga pelatihan penting untuk dilakukan dalam suatu organisasi.

Teori TAM (Technology Acceptance Model) menggunakan dasar atas dua persepsi dalam meningkatkan kinerja. Adanya pelatihan sistem informasi bagi pengguna, memberikan kemudahan dan manfaat dari sistem tersebut. Sehingga terjadi kepuasan karyawan atas sistem tersebut yang berdampak pada kinerja pengguna.

Berdasarkan beberapa hasil penelitian terdahulu mendukung teori diatas seperti, seperti Damana dan Suardikha (2016), menyatakan bahwa pelatihan 
Ni Made Sri Pawitri dan Made Yenni Latrini. Pengaruh ...

berpengaruh positif pada kinerja, dan menurut Wulandari dan Juliarsa (2017), juga mengatakan hal yang sama yaitu pelatihan berpengaruh positif pada kinerja karyawan. Sejalan dengan penelitian tersebut, menurut Belawa dan Putra (2018), menyatakan hasil penelitian bahwa pelatihan berpengaruh positif pada kinerja karyawan di Kantor Dinas Perindustrian dan Perdagangan Kota Denpasar.Berdasarkan penjelasan diatas, maka dapat dirumuskan hipotesis sebagai berikut:

$\mathrm{H}_{2}$ : Pelatihan kerja berpengaruh positif pada kinerja karyawan.

Setiap individu memiliki pandangan yang berbeda atas pengendalian terhadap setiap peristiwa yang dihadapinya yang disebut locus of control. Locus of control menjadi dua yaitu locus of control eksternal menganggap bahwa setiap peristiwa yang terjadi merupakan nasib dan bukan atas perbuatan dirinya dan locus of control internal yang lebih menghadapi setiap peristiwa dan menganggap kejadian yang terjadi atas dasar perbuatannya, sehingga seseorang seperti ini akan lebih mudah bertanggung jawab dan motivasi yang disalurkan juga lebih tinggi (Manichander, 2014). Jika dilihat dari sisi kinerja, maka seseorang dengan locus of control internal, lebih mampu untuk meningkatkan kinerjanya, dibandingkan dengan karyawan yang memiliki locus of control eksternal.

Teori TAM (Technology Acceptance Model) menyatakan bahwa penerimaan pengguna atas penerapan sistem informasi didasarkan pada dua persepsi, yaitu persepsi kebermanfaatan dan persepsi kemudahan. Dengan demikian, semakin seseorang merasa yakin bahwa sistem informasi yang digunakan mendatangkan kemudahan dan manfaat, maka akan semakin besar 
penerimaan penerapan sistem informasi tersebut. Penerapan sistem informasi selanjutnya akan membantu pekerjaan sehingga kinerja meningkat.

Berdasarkan beberapa hasil penelitian terdahulu mendukung teori diatas seperti, bahwa locus of control internal berpengaruh positif pada kinerja karyawan (Hermawan dan Kaban, 2014). Sejalan dengan penelitian tersebut, menurut Puspitayanti (2015), menyatakan bahwa locus of control internal berpengaruh pada kinerja karyawan dan Rahayu dan Badera (2017), yang menyatakan hal yang sama, yaitu locus of control internal berpengaruh positif pada kinerja karyawan.Berdasarkan penjelasan maka dapat dirumuskan hipotesis, sebagai berikut:

$\mathrm{H}_{3}$ : Locus of control internal berpengaruh positif pada kinerja karyawan.

\section{METODE PENELITIAN}

Lokasi atau ruang lingkup wilayah penelitian ini dilakukan pada Lembaga Perkreditan Desa (LPD) di Kota Denpasar. LPD adalah lembaga keuangan yang unik yang berada di desa pakraman di provinsi Bali. LPD dipilih karena proses kepemilihan pengurus LPD tidak berdasarkan latar belakang pendidikan dalam bidang tertentu melainkan berdasarkan paruman (musyawarah), sehingga kemampuan karyawan LPD diragukan untuk mencapai peningkatan kinerja. Walaupun demikian, kinerja LPD dapat mencapai suatu keberhasilan, seperti LPD yang berada di Kota Denpasar. Alasan peneliti memilih LPD di Kota Denpasar, karena mengalami perkembangan aset di atas $\mathrm{Rp} 1.000 .000 .000 .000$ setiap tahunnya sejak 2015 dan seluruh LPD di Kota Denpasar telah menerapkan SIA. Berdasarkan data yang diperoleh dari Lembaga Pemberdayaan Lembaga 
Ni Made Sri Pawitri dan Made Yenni Latrini. Pengaruh ...

Perkreditan Desa (LPLPD) terdapat 35 LPD di Kota Denpasar dan memiliki karyawan berjumlah 480 orang.

Analisis regresi digunakan untuk meramalkan atau memperkirakan nilai dari satu variable dalam hubungannya dengan variable lain yang diketahui melalui persamaan garis regresinya. Model regresi linier berganda yang digunakan adalah dengan menggunakan rumus:

$\mathrm{Y}=\alpha+\beta_{1} \mathrm{X}_{1}+\beta_{2} \mathrm{X}_{2}+\beta_{3} \mathrm{X}_{3}+\varepsilon$

Keterangan:

$\mathrm{Y} \quad=$ Kinerja karyawan

$\alpha \quad=$ Konstanta

$\beta_{1} \quad=$ Koefisien regresi variable efektivitas SIA

$\beta_{2} \quad=$ Koefisien regresi variable pelatihan kerja

$\beta_{3} \quad=$ Koefisien regresi variable locus of control internal

$\mathrm{X}_{1} \quad=$ Efektivitas SIA

$\mathrm{X}_{2} \quad=$ Pelatihan SIA

$\mathrm{X}_{3}=$ Locus of control internal

$\varepsilon \quad=$ Error

\section{HASIL DAN PEMBAHASAN}

Usia karyawan LPD di Kota Denpasar bervariasi, adapun usia yang mendominasi berada pada kisaran usia lebih dari 50 tahun dengan jumlah 42 orang (40\%). Kemudian, karyawan dengan kisaran umur 41-50 tahun sebesar 39 orang (37,14\%), 30-40 tahun berjumlah 17 orang (16,19\%), dan kurang dari 30 tahun berjumlah 7 orang $(6,67 \%)$.

Penelitian ini lebih banyak responden dengan jenis kelamin laki-laki yaitu sebesar 62 orang $(59,05 \%)$ dibandingkan responden dengan jenis kelamin perempuan, yaitu hanya berjumlah 43 orang (40,95\%). Kondisi ini berarti kaum 
laki-laki lebih mendominasi sebagai karyawan LPD, khususnya LPD Kota Denpasar.

Jenjang pendidikan responden dalam penelitian ini berada pada tingkat SMA yaitu sebesar 59 orang (56,19\%). Jumlah tersebut terbilang cukup jauh jika dibandingkan dengan responden yang jenjang pendidikan terakhirnya diploma sebesar 21 orang (20\%), sarjana (S1) sebesar 23 orang $(21,9 \%)$, dan pasca sarjana (S2) hanya berjumlah 2 orang $(1,91 \%)$.

Karyawan LPD yang menjadi responden paling banyak memiliki masa kerja diatas 15 tahun yaitu sebesar 50 orang $(47,62 \%)$, kemudian diikuti dengan karyawan yang memiliki masa kerja 6-10 tahun sebesar 20 orang $(19,05 \%)$. Jumlah ini tidak berbanding jauh dengan karyawan yang memiliki masa kerja 1115 tahun yaitu sebesar 18 orang $(17,14 \%)$ dan karyawan dengan masa kerja 1-5 tahun yaitu sebesar 17 orang $(16,19 \%)$

Tabel 2.

Hasil Uji Statistik Deskriptif

\begin{tabular}{lccccc}
\hline & \multicolumn{5}{c}{ Descriptive Statistics } \\
\multicolumn{1}{c}{ Variabel } & $\mathrm{N}$ & Min. & Maks. & Mean & StandarDeviasi \\
\hline $\mathrm{X}_{1}$ & 105 & 16 & 25 & 22,10 & 2,106 \\
$\mathrm{X}_{2}$ & 105 & 15 & 25 & 20,94 & 2,240 \\
$\mathrm{X}_{3}$ & 105 & 8 & 15 & 12,41 & 1,691 \\
$\mathrm{Y}$ & 105 & 17 & 25 & 22,00 & 2,291 \\
Valid N (listwise) & 105 & & & &
\end{tabular}

Berdasarkan Tabel 2 total sampel yang digunakan adalah 105 responden. Variabel efektivitas penggunaan SIA memiliki nilai minimum 16, nilai maksimum 25 dan nilai rata-rata sebesar 22,10. Hal tersebut menunjukkan bahwa efektivitas penggunaan SIA pada karyawan LPD di Kota Denpasar rata-rata tinggi. Nilai standar deviasi variabel efektivitas penggunaan SIA sebesar 2,106. Hal ini berarti berdasarkan hasil statistik deskriptif terjadi perbedaan nilai efektivitas 
Ni Made Sri Pawitri dan Made Yenni Latrini. Pengaruh ...

penggunaan SIA yang diteliti terhadap nilai rata-ratanya sebesar 2,106 dan nilai standar deviasi lebih rendah dibandingkan dengan nilai rata-rata, yang artinya sebaran data terkait efektivitas penggunaan SIA sudah merata.

Berdasarkan Tabel 2 total sampel yang digunakan adalah 105 responden. Variabel pelatihan SIA memiliki nilai minimum 15, nilai maksimum 25 dan nilai rata-rata sebesar 20,94. Hal tersebut menunjukkan bahwa pelatihan SIA pada karyawan LPD di Kota Denpasar rata-rata tinggi. Nilai standar deviasi variabel pelatihan SIA sebesar 2,240. Hal ini berarti berdasarkan hasil statistik deskriptif terjadi perbedaan nilai pelatihan SIA terhadap nilai rata-ratanya sebesar 2,240 dan standar deviasi lebih rendah dibandingkan dengan nilai rata-rata, yang artinya sebaran data terkait pelatihan SIA sudah merata.

Berdasarkan Tabel 2 total sampel yang digunakan adalah 105 responden. Variabel locus of control internal memiliki nilai minimum 8, nilai maksimum 15 dan nilai rata-rata sebesar 12,41. Hal tersebut menunjukkan bahwa locus of control internal karyawan LPD di Kota Denpasar rata-rata tinggi. Nilai standar deviasi variabel locus of control internal 1,691. Hal ini berarti bedasarkan hasil statistik deskriptif terjadi perbedaan nilai locus of control internal terhadap nilai rata-ratanya sebesar 1,691 dan standar deviasi lebih rendah dibandingkan dengan nilai rata-rata, yang artinya sebaran data terkait locus of control internal sudah merata.

Berdasarkan Tabel 2 total sampel yang digunakan adalah 105 responden. Variabel kinerja karyawan memiliki nilai minimum 17 , nilai maksimum 25 , dan nilai rata-rata sebesar 22,00. Hal tersebut menunjukkan bahwa kinerja karyawan 
LPD di Kota Denpasar rata-rata tinggi. Nilai standar deviasi variabel kinerja karyawan 2,291. Hal ini berarti berdasarkan hasil statistik deskriptif terjadi perbedaan nilai kinerja karyawan terhadap nilai rata-ratanya sebesar 2,291 dan standar deviasi lebih rendah dibandingkan dengan nilai rata-rata, yang artinya sebaran data terkait kinerja karyawan sudah merata.

Uji normalitas bertujuan untuk menguji apakah dalam model regresi, data variabel memiliki distribusi normal atau tidak normal. Metode yang digunakan adalah statistik Kolmogorov-Smirnov. Jika Asymp. Sig (2-tailed) lebih besar dari level of significance 0,05 yang dipakai, maka dapat disimpulkan bahwa data variabel dikatakan terdistribusi secara normal. Hasil uji normalitas dapat dilihat pada Tabel 3 sebagai berikut.

Tabel 3.

Hasil Uji Normalitas

\begin{tabular}{llr}
\hline & & $\begin{array}{c}\text { Unstandardized } \\
\text { Residual }\end{array}$ \\
\hline $\mathrm{N}$ & Mean & 105 \\
Normal Parameters ${ }^{\mathrm{a}, \mathrm{b}}$ & Std. Deviation &, 00000000 \\
& Absolute & 1,363852133 \\
Most Extreme Differences & Positive &, 077 \\
& Negative &, 054 \\
Kolmogorov-Smirnov Z & &,- 077 \\
Asymp. Sig. (2-tailed) & &, 793 \\
Sumber:Data diolah, 2018 & &, 555 \\
\hline
\end{tabular}

Berdasarkan Tabel 3 dapat dilihat bahwa nilai Asymp.Sig. (2-tailed) sebesar 0,555 lebih besar dari $\alpha=0,05$, maka ini berarti bahwa residual dari model telah terdistribusi secara normal.

Uji multikolinearitas bertujuan untuk mengetahui apakah pada model regresi ditemukan adanya korelasi antar variabel bebas. Model regresi yang baik adalah model regresi yang bebas dari multikolinearitas, yaitu memiliki nilai 
Ni Made Sri Pawitri dan Made Yenni Latrini. Pengaruh ...

tolerance variabel bebas yang lebih dari $10 \%$ atau 0,10 atau nilai variance inflation factor (VIF) kurang dari 10. Hasil uji mltikolinearitas dapat dilihat pada Tabel 4 sebagai berikut.

Tabel 4.

Hasil Uji Multikolinearitas

\begin{tabular}{llcc}
\hline & \multicolumn{2}{c}{ Model } & \multicolumn{2}{c}{ Collinearity Statistics } \\
& (Constant) & & VIF \\
\hline 1 & $\mathrm{X}_{1}$ &, 601 & 1,664 \\
& $\mathrm{X}_{2}$ &, 686 & 1,458 \\
& $\mathrm{X}_{3}$ &, 583 & 1,715 \\
\hline
\end{tabular}

Sumber: Data diolah, 2018

Berdasarkan Tabel 4menunjukkan bahwa variabel bebas memiliki nilai tolerance lebih dari 0,1 atau nilai VIF kurang dari 10, maka dapat dikatakan bahwa pada model regresi tidak terjadi gejala multikolinearitas.

. Model regresi yang baik adalah model regresi yang tidak mengandung gejala heteroskedastisitas atau mempunyai varians yang homogen, yaitu bila nilai signifikansi variabel bebasnya terhadap nilai absolute residual statistik lebih besar dari $\alpha=0,05$. Hasil uji heteroskedastisitas dapat dilihat pada Tabel 5 sebagai berikut.

Tabel 5.

Hasil Uji Heteroskedastisitas

\begin{tabular}{ccc}
\hline Model & Sig. & Keterangan \\
\hline X1 &, 230 & Bebas Heteroskedastisitas \\
X2 &, 095 & Bebas Heteroskedastisitas \\
X3 &, 295 & Bebas Heteroskedastisitas \\
\hline
\end{tabular}

Sumber: Data diolah, 2018

Berdasarkan Tabel 5 menunjukkan bahwa nilai Sig. Dari masing-masing variabel tersebut diatas 0,05 sehingga seluruh variabel tersebut dapat dikatakan bebas dari heteroskedastisitas. 
Analisis regresi linier berganda bertujuan untuk mengukur besarnya pengaruh variabel bebas terhadap variabel terikat dan memprediksi variabel terikat dengan menggunakan variabel bebas. Hasil analisis regresi linier berganda dapat dilihat Tabel 6 sebagai berikut:

Tabel 6.

Hasil Uji Regresi Linier Berganda

\begin{tabular}{|c|c|c|c|c|c|c|}
\hline & \multirow[t]{2}{*}{ Model } & \multicolumn{2}{|c|}{ Unstandardized Coefficients } & \multirow{2}{*}{$\begin{array}{c}\text { Standardized } \\
\text { Coefficients } \\
\text { Beta }\end{array}$} & \multirow[t]{2}{*}{$\mathrm{T}$} & \multirow[t]{2}{*}{ Sig. } \\
\hline & & $\mathrm{B}$ & Std. Error & & & \\
\hline \multirow[t]{4}{*}{1} & (Constant) & 4,214 & 1,574 & & 2,676 & ,009 \\
\hline & $\mathrm{X}_{1}$ & ,262 & ,083 & ,248 & 3,147 & ,002 \\
\hline & $\mathrm{X}_{2}$ & ,200 & 073 & ,202 & 2,740 & ,007 \\
\hline & $\mathrm{X}_{3}$ & 629 & 105 & ,479 & 5,984 &, 000 \\
\hline
\end{tabular}

Berdasarkan Tabel 6, diperoleh suatu persamaan regresi sebagai berikut:

$$
Y=4,214+0,262 X_{1}+0,200 X_{2}+0,629 X_{3}+\varepsilon
$$

Nilai konstanta $(\alpha)$ menunjukkan nilai positif sebesar 4,214 menyatakan bahwa jika variabel independen yaitu efektivitas penggunaan SIA, pelatihan SIA, dan locus of control internal dinyatakan konstan pada angka nol, maka nilai variabel dependen yaitu kinerja karyawan (Y) sebesar 4,214.

Koefisien variabel efektivitas penggunaan SIA $\left(\beta_{1}\right)$ sebesar 0,262 , artinya apabila nilai variabel efektivitas penggunaan SIA mengalami kenaikan 1\%, maka kinerja karyawan akan mengalami peningkatan sebesar $26,2 \%$ dengan asumsi nilai variabel independen lainnya tidak berubah (konstan).

Koefisien variabel pelatihan SIA $\left(\beta_{2}\right)$ sebesar 0,2 , artinya apabila nilai variabel pelatihan SIA mengalami kenaikan 1\%, maka kinerja karyawan akan mengalami peningkatan sebesar $20 \%$ dengan asumsi nilai variabel independen lainnya tidak berubah (konstan). 
Ni Made Sri Pawitri dan Made Yenni Latrini. Pengaruh ...

Koefisien variabel locus of control internal $\left(\beta_{3}\right)$ sebesar 0,629 , artinya apabila nilai variabel locus of control internal mengalami kenaikan 1\%, maka kinerja karyawan akan mengalami peningkatan sebesar 62,9\% dengan asumsi nilai variabel independen lainnya tidak berubah (konstan).

Koefisien determinasi dilakukan untuk mengukur seberapa besar variabel bebas mampu menjelaskan perubahan variabel terikatnya. Koefisien determinasi yang digunakan pada analisis regresi linear berganda adalah dengan melihat nilai Adjusted RSquare. Hasil koefisien determinasi dapat dilihat pada Tabel 7 sebagai berikut:

Tabel 7.

Hasil Koefisien Determinasi

\begin{tabular}{lrrrrr}
\hline Model & & & & \multicolumn{2}{c}{$\begin{array}{c}\text { Std. Error of the } \\
\text { Estimate }\end{array}$} \\
\hline 1 & & R Square & Adjusted R Square &, 611 & 1,384 \\
\hline
\end{tabular}

Sumber: Data diolah, 2018

Berdasarkan Tabel 2 dapat dilihat bahwa nilai Adjusted $R$ Square pada model sebesar 0,611. Nilai Adjusted $R$ Square pada model artinya variabel kinerja karyawan dapat dijelaskan oleh variabel efektivitas penggunaan SIA, pelatihan SIA, dan locus of control internal sebesar $61,1 \%$, sedangkan sisanya dijelaskan oleh variabel lain diluar model. Standar Error of the Estimate (SEE) sebesar 1,384, yang artinya semakin kecil nilai SEE akan membuat model regresi semakin tepat dalam memprediksi variabel independen.

Uji kelayakan model (uji F) bertujuan untuk mengetahui apakah setidaknya satu dari semua variabel independen yang digunakan dalam model mempunyai pengaruh pada variabel dependen/terikat. Hasil uji kelayakan model (uji F) dapat dilihat pada Tabel 8 sebagai berikut: 
Tabel 8.

Hasil Uji F

\begin{tabular}{llrrrrr}
\hline Model & & Sum of Squares & Df & Mean Square & \multicolumn{1}{c}{ F } & \multicolumn{1}{c}{ Sig. } \\
\hline 1 & Regression & 318,550 & 3 & 106,183 & 55,438 &, $000^{\mathrm{a}}$ \\
& Residual & 193,450 & 101 & 1,915 & & \\
& Total & 512,000 & 104 & & & \\
\hline
\end{tabular}

Sumber:Data diolah, 2018

Berdasarkan Tabel 8 dapat dilihat bahwa pada model memiliki nilai Sig. sebesar 0,00 lebih kecil dari $\alpha=0,05$, menunjukkan model penelitian ini layak untuk digunakan sebagai alat analisis untuk menguji pengaruh variabel independen terhadap variabel dependen. Hal ini berarti bahwa variabel efektivitas penggunaan SIA, pelatihan SIA, dan locus of control internal berpengaruh secara bersama-sama terhadap variabel dependennya yaitu kinerja karyawan.

Uji statistik t bertujuan untuk menunjukkan seberapa tingkat pengaruh satu variabel independen secara individual dalam menerangkan variabel dependen. Uji statistik t dilakukan dengan membandingkan hasil nilai signifikansi $\alpha=0,05$. Hasil uji statistik t dapat dilihat pada Tabel 9 sebagai berikut:

Tabel 9.

Hasil Uji t

\begin{tabular}{ccccc}
\hline Variabel & $\begin{array}{c}\text { Koefisien } \\
\text { Regresi }\end{array}$ & $\mathrm{t}_{\text {hitung }}$ & Sig. & Hasil Hipotesis \\
\hline Efektivitas Penggunaan SIA &, 262 & 3,147 &, 002 & $\mathrm{H}_{1}$ Diterima \\
Pelatihan SIA &, 200 & 2,740 &, 007 & $\mathrm{H}_{2}$ Diterima \\
Locus of Control Internal &, 629 & 5,984 &, 000 & $\mathrm{H}_{3}$ Diterima \\
\hline
\end{tabular}

Sumber: Data diolah, 2018

Hipotesis pertama menyatakan bahwa efektivitas penggunaan SIA berpengaruh positif pada kinerja karyawan. Pada Tabel 9 dapat dilihat bahwa nilai signifikansi uji t untuk variabel efektivitas penggunaan SIA sebesar 0,002 yaitu lebih kecil dari $\alpha=0,05$ dengan koefisien regresi bernilai positif sebesar 0,262. Berdasarkan hal tersebut, maka hipotesis pertama $\left(\mathrm{H}_{1}\right)$ dalam penelitian ini 
Ni Made Sri Pawitri dan Made Yenni Latrini. Pengaruh ...

diterima. Artinya secara parsial efektivitas penggunaan SIA berpengaruh positif pada kinerja karyawan.

Hipotesis kedua menyatakan bahwa pelatihan SIA berpengaruh positif pada kinerja karyawan. Pada Tabel 9 dapat dilihat bahwa nilai signifikansi uji t untuk variabel pelatihan SIA sebesar 0,007 yaitu lebih kecil dari $\alpha=0,05$ dengan koefisien regresi bernilai positif sebesar 0,2. Berdasarkan hal tersebut, makahipotesis kedua $\left(\mathrm{H}_{2}\right)$ dalam penelitian ini diterima. Artinya secara parsial pelatihan SIA berpengaruh positif pada kinerja karyawan.

Hipotesis ketiga menyatakan bahwa locus of control internal berpengaruh positif pada kinerja karyawan. Pada Tabel 9 dapat dilihat bahwa nilai signifikansi uji t untuk variabel locus of control internal sebesar 0,000 yaitu lebih kecil dari $\alpha$ $=0,05$ dengan koefisien regresi bernilai positif sebesar 0,629. Berdasarkan hal tersebut, maka hipotesis ketiga $\left(\mathrm{H}_{3}\right)$ dalam penelitian ini diterima. Artinya secara parsial locus of control internal berpengaruh positif pada kinerja karyawan.

Berdasarkan hasil penelitian menunjukkan bahwa efektivitas penggunaan SIA berpengaruh positif dan signifikan pada kinerja karyawan sehingga hipotesis pertama $\left(\mathrm{H}_{1}\right)$ dalam penelitian ini diterima. Hal ini berarti bahwa jika terjadi peningkatan pada efektivitas penggunaan SIA, maka akan meningkatkan kinerja karyawan juga. Hasil ini juga didukung oleh teori Technology Acceptance Model (TAM) yang menyatakan bahwa penggunaan sistem informasi akuntansi didasarkan oleh dua keyakinan yaitu berdasarkan persepsi kemudahan dan kebermanfaatan. Semakin efektif penggunaan sistem informasi akuntansi menunjukkan sistem informasi tersebut memberikan kemudahan dan manfaat bagi 
penggunanya atau karyawan. Jadi, dengan penggunaan sistem informasi akuntansi di LPD membantu karyawan untuk menghasilkan informasi yang akurat, tepat waktu, dan dapat dipercaya yang nantinya dapat meningkatkan kinerja karyawan.

Hasil penelitian ini didukung oleh penelitian Samuel (2013), Sugiartini dan Dharmadiaksa (2016), Lukiman dan Lestarianto (2016), Cahyanti dan Suartana (2018), yang menunjukkan bahwa efektivitas penggunaan SIA berpengaruh positif pada kinerja karyawan.

Berdasarkan hasil penelitian menunjukkan bahwa pelatihan SIA berpengaruh positif dan signifikan pada kinerja karyawan sehingga hipotesis kedua $\left(\mathrm{H}_{2}\right)$ dalam penelitian ini diterima. Hal ini berarti bahwa jika terjadi peningkatan pada pelatihan SIA, maka akan meningkatkan kinerja karyawan juga. Hasil ini juga didukung oleh teori Technology Acceptance Model (TAM) yang menyatakan bahwa perilaku pengguna terhadap sistem informasi didasarkan oleh dua keyakinan yaitu berdasarkan persepsi kemudahan dan kebermanfaatan. Semakin mudah dan bermanfaat pengguna menggunakan sistem informasi, akan meningkatkan kinerja, salah satunya melalui tingkat frekuensi pelatihan SIA yang tinggi, maka akan semakin meningkatkan kerja karyawan pengguna SIA, karena pengguna akan merasakan manfaat dan kemudahan dalam penggunaan SIA tersebut.

Hasil penelitian ini didukung oleh penelitian Dwijayanthi dan Dharmadiaksa (2013), Sarastini dan Suardikha (2017), Dhana dan Pande (2018), dan Halawi and Haydar (2018) yang menunjukkan bahwa pelatihan SIA berpengaruh positif pada kinerja karyawan. 
Ni Made Sri Pawitri dan Made Yenni Latrini. Pengaruh ...

Berdasarkan hasil penelitian menunjukkan bahwa locus of control internal berpengaruh positif dan signifikan pada kinerja karyawan sehingga hipotesis ketiga $\left(\mathrm{H}_{3}\right)$ dalam penelitian ini dapat diterima. Locus of control dapat dianggap sebagai kepribadian utama untuk mempengaruhi perilaku di suatu organisasi (Turker dan Inel, 2012). Hal ini berarti bahwa jika terjadi peningkatan keyakinan individu locus of control internal, maka akan meningkatkan kinerja karyawan juga. Hasil ini juga didukung oleh teori Technology Acceptance Model (TAM) yang menyatakan bahwa perilaku pengguna terhadap sistem informasi didasarkan oleh dua keyakinan yaitu berdasarkan persepsi kemudahan dan kebermanfaatan. Dengan demikian, semakin seseorang merasa yakin bahwa sistem informasi yang digunakan mendatangkan kemudahan dan manfaat, maka akan semakin besar penerimaan penerapan sistem informasi tersebut. Penerapan sistem informasi selanjutnya akan membantu pekerjaan sehingga kinerja meningkat.

Hasil penelitian ini didukung oleh penelitian dari Mali (2013), Putri dan Suprasto H (2016), Mahendra dan Yenni (2016) dan Suci dan Ariyanto (2018), yang menunjukkan bahwa locus of control internal berpengaruh positif pada kinerja.

Penelitian ini memberikan manfaat dalam menambah wawasan dan ilmu pengetahuan mengenai pentingnya penerapan sistem informasi akuntansi yang berdasarkan teknologi terkomputerisasi, pelatihan sistem informasi akuntansi dan keyakinan locus of control di lingkungan kerja terutama LPD wilayah Kota Denpasar. Hasil uji dalam penelitian ini menunjukkan variabel efektivitas penggunaan SIA, pelatihan SIA, dan locus of control internal berpengaruh positif 
pada kinerja karyawan. Hasil penelitian ini mendukung teori Technology Acceptance Model (TAM) bahwa penerapan suatu teknologi sistem informasi tergantung dari penggunanya untuk menerima atau menolak penggunaan sistem tersebut. Dengan diterimanya suatu sistem informasi oleh pengguna, maka akan memberikan kemudahan dan manfaat pada pengguna sistem yang akan berpengaruh pada kinerja karyawan.

Penelitian ini mampu memberikan kontribusi positif bagi semua pihak, terutama pihak karyawan LPD. Bagi karyawan LPD hendaknya bersungguhsungguh dalam melaksanakan tugas atau pekerjaan, mengikuti pelatihan yang telah dilaksanakan oleh LPLPD, dan mampu menggunakan sistem informasi dengan efektif, karena tidak dapat dipungkiri bahwa sistem informasi sangat penting dalam memberikan kemudahan dan manfaat dalam menghasilkan informasi bagi pihak yang membutuhkan. Dengan demikian, melalui sistem informasi akuntansi diharapkan kinerja karyawan akan meningkat kemudian dapat berpengaruh positif pada kinerja LPD yang semakin maju.

\section{SIMPULAN}

Efektivitas penggunaan SIA berpengaruh positif pada kinerja karyawan LPD di Kota Denpasar. Ini berarti bahwa, semakin tinggi tingkat keefektifan penggunaan SIA, maka akan meningkatkan kinerja karyawan LPD di Kota Denpasar. Pelatihan SIA berpengaruh positif pada kinerja karyawan LPD di Kota Denpasar. Ini berarti bahwa, semakin tinggi frekuensi diadakannya pelatihan SIA pada LPD, akan meningkatkan kinerja karyawan LPD di Kota Denpasar. 
Ni Made Sri Pawitri dan Made Yenni Latrini. Pengaruh ...

Locus of control internal berpengaruh positif pada kinerja karyawan LPD di Kota Denpasar. Ini berarti bahwa, apabila seseorang telah memiliki keyakinan dan minat dari individunya sendiri untuk menggunakan SIA, maka akan meningkatkan kinerja karyawan LPD di Kota Denpasar.

LPD sebaiknya mampu meningkatkan penggunaan sistem informasi akuntansi oleh karyawannya, sehingga dapat menghasilkan kinerja LPD yang lebih baik dari segi penggunaan teknologi. Kinerja yang lebih baik dapat dicapai melalui memaksimalkan penggunaan SIA dengan diawasi oleh pihak pimpinan LPD (pengawas). Berdasarkan hasil kuesioner, didapat bahwa rata-rata untuk indikator pengukuran pelatihan yang ketiga memiliki rata-rata dengan nilai terkecil, dimana indikator ketiga tersebut adalah materi pelatihan. LPLPD yang melaksanakan pelatihan seharusnya lebih mempersiapkan pelaksanaan pelatihan dari segi materi pelatihan agar sesuai dengan kebutuhan karyawan, sehingga pelatihan akan lebih efektif dalam meningkatkan kinerja karyawan. Selain itu, perlu untuk melakukan sosialisasi dan update sistem bagi LPD agar penggunaan sistem informasi akuntansi menjadi lebih maksimal.

Penelitian ini menggunakan variabel efektivitas penggunaan SIA, pelatihan SIA, dan locus of control internal dengan nilaiAdjusted $R$ Squaresebesar $61,1 \%$. Hal ini berarti kemampuan variabel efektivitas penggunaan SIA, pelatihan SIA, dan locus of control internal dalam menjelaskan variabel kinerja karyawan sebesar $61,1 \%$, dan sisanya dijelaskan oleh variabel diluar model. Bagi penelitian selanjutnya disarankan untuk menambah variabel lain diluar model penelitian ini untuk diuji pengaruhnya terhadap kinerja karyawan seperti model kepemimpinan, 
kecanggihan teknologi, dan kenyamanan fisik pengguna sistem informasi. Selain itu, bagi penelitian selanjutnya sebaiknya memiliki data yang lebih rinci dan mendalam terkait penggunaan sistem informasi akuntansi pada LPD apakah sudah menggunakan sistem LPD acuan dari BKS-LPD atau hanya menggunakan perangkat komputer saja, sehingga penelitian selanjutnya dapat membedakan penelitian antara LPD yang menggunakan sistem BKS-LPD dan LPD yang hanya menggunakan sistem komputer tanpa sistem untuk diketahui pengaruhnya pada kinerja karyawan LPD.

\section{REFERENSI}

Al-Eqab, M., \& Adel, D. (2013). The Impact of IT Sophistications on the Perceived Usefulness of Accounting Information Characteristics among Jordanian Listed Companies, 4(3), 145-155.

Ariputra, I. W. K., \& Suaryana, I. G. N. A. (2018). Budaya Organisasi Memoderasi Pengaruh Efektivitas Penerapan SIA dan Kesesuaian Tugas dengan TI Terhadap Kinerja Karyawan. E-Jurnal Akuntansi Universitas Udayana, 22, 216-244.

Artanaya, I. M. D. D., \& Gayatri. (2016). Kepercayaan Memoderasi Pengaruh Efektivitas Sistem Informasi Akuntansi Terhadap Kinerja Individual pada Lembaga Perkreditan Desa. E-Jurnal Akuntansi Universitas Udayana, 17, 1575-1602.

Ayu Artha Dewi, N. L., \& Dharmadiaksa, I. B. (2017). Pengaruh Efektivitas SIA, Pemanfaatan TI dan Kemampuan Teknis Pemakai SIA terhadap Kinerja Individu. E-Jurnal Akuntansi Universitas Udayana, 18, 386-414.

Belawa, P. D., \& Putra, I. M. P. D. (2018). Pengaruh Intensif , Tingkat Pendidikan , Pelatihan dan Pengalaman Kerja Pada Kinerja Individu Pengguna Sistem Informasi Akuntansi. E-Jurnal Akuntansi Universitas Udayana, 22, 653682.

Bodnar, G. H., \& Hopwood, W. S. (2006). Sistem Informasi Akuntansi (Buku I). Jakarta: Salemba Empat. 
Ni Made Sri Pawitri dan Made Yenni Latrini. Pengaruh ...

Cahyanti, I. G. A. D., \& Suartana, I. W. (2018). Pengaruh Efektivitas Sistem Informasi Akuntansi Terhadap Kinerja Karyawan dengan Budaya Organisasi Sebagai Variabel Moderasi. E-Jurnal Akuntansi Universitas Udayana, 23, 2090-2117.

Damana, A. W. A., \& Suardikha, I. M. S. (2016). Pengaruh Keterlibatan Pemakai, Pelatihan, Ukuran Organisasi dan Keahlian Pemakai Terhadap Kinerja Sistem Informasi Akuntansi. E-Jurnal Akuntansi Universitas Udayana, 1452-1480.

Davis, F. D. (2015). Perceived Usefulness, Perceived Ease of Use , and User Acceptance of Information Technology. Management Information Systems Research Center, (SEPTEMBER 1989). https://doi.org/10.2307/249008

Dwijayanthi, Di. M., \& Dharmadiaksa, I. B. (2013). Pengaruh Insentif, Tingkat Pendidikan, Pelatihan dan Pengalaman Kerja pada Kinerja Individu Pengguna Sistem Informasi Akuntansi SKPD DISPENDA Kota Denpasar. E-Jurnal Akuntansi Universitas Udayana, 2, 332-344.

Edison, E., Anwar, Y., \& Komariyah, I. (2017). Manajemen Sumber Daya Manusia. Bandung: ALFABETA.

Engetou, E. (2017). The Impact of Training and Development on Organizational Performance Case Study: National Financial Credit Bank Kumba. Centria University Of Applied Sciences, (May).

Esmeray, A. (2016). The Impact of Accounting Information Systems on Firm Performance: Empirical Evidence in Turkish Small and Medium Sized Enterprises. International Review of Management and Marketing, 6(2), 233236.

Fatmayoni, I. G. A. A. I., \& Yadnyana, I. K. (2017). Pengaruh Efektivitas SIA dan Pengunaan Teknologi Informasi pada Kinerja Individual dengan Insentif Karyawan sebagai Pemoderasi. E-Jurnal Akuntansi Universitas Udayana, 19, 2175-2204.

Fitri Ani, N. (2016). Analisis Pengaruh Locus of Control dan Stres Kerja Terhadap Kinerja Karyawan Perspektif Etika Kerja Islam.

Halawi, A., \& Haydar, N. (2018). Effects of Training on Employee Performance. International Journal Humanities Studies, 5(2)(June), 2311-7796.

Harash, E., Al-timimi, S., \& Radhi, A. H. (2014). The Influence of Accounting Information Systems ( AIS ) on Performance of Small and Medium Enterprises ( SMEs ) in Iraq. Science and Education Centre of North America, 3(4), 48-57. https://doi.org/10.12735/jbm.v3i4p48 
Hermawan, F., \& Kaban, D. F. (2014). Pengaruh Locus Of Control Terhadap Kinerja Karyawan ( Studi Pada Karyawan Di PT X ). E-Journal Atma Jaya, $5(1)$.

Husna, A. M., Suarman, \& Ngadlan. (n.d.). Pengaruh Tingkat Satuan Pendidikan dan Pelatihan Terhadap Kinerja Karyawan PT. Bank Riau KEPRI Kantor Pusat Pekanbaru. Jurnal Ekonomi Dan Bisnis Universitas Riau, 1-10.

Imbiri, W. (2014). AIS Quality and Effectiveness of the Decision Making Process in the use of the ERPS. Research Journal of Finance and Accounting, (January 2013).

Irma Diana Putri, N. W., \& Dharmadiaksa, I. B. (2015). Pengaruh Kemampuan Teknik Personal, Program Pelatihan dan Pendidikan, Insentif, dan Partisipasi Manajemen pada Kinerja Penerapan SIA. E-Jurnal Akuntansi Universitas Udayana, 3, 582-592.

Lucyanda, J. (2010). Pengujian Technology Acceptance Model (TAM) dan Theory Planned Behavior (TPB). JRAK UNISMA, 2(1995), 1-14.

Lukiman, R. H., \& Lestarianto, J. W. (2016). Pengaruh Penerapan Sistem Informasi Akuntansi, Efektivitas Penggunaan Sistem Informasi Akuntansi, Kepercayaan atas Teknologi Sistem Informasi Akuntansi dan Teknologi Informasi Terhadap Kinerja Individu Karyawan. Ultima Accounting, 8(2), $46-65$.

Mahendra Putra, I. G. A., \& Yenni Latrini, M. (2016). Pengaruh Locus of Control dan Komitmen Profesional pada Kinerja Auditor Internal. E-Jurnal Akuntansi Universitas Udayana, 17, 1808-1833.

Mali, V. (2013). A Study on Locus of Control and its Impact on Employees ' Performance. International Journal of Science and Research, 2(12), 149151.

Manichander, T. (2014). Locus of Control and Performance: Widening Applicabilities. PARIPEX-Indian Journal Of Research, (1990), 1990-1992.

Medina, J., Jiménez, D. K., Álberto, M., \& Abrego, M. S. D. (2014). Training in Accounting Information Systems for Users' Satisfaction and Decision Making. International Journal of Business and SOcial Science, 5(7), 134144.

Mindarti, C. S. (2015). Pengaruh Karakteristik Individu Terhadap Kinerja Auditor. Jurnal Ekonomi Dan Bisnis Universitas STIKUBANK, XVIII(3), 5974. 
Ni Made Sri Pawitri dan Made Yenni Latrini. Pengaruh ...

Novia Puspitasari, N. W., \& Juliarsa, G. (2017). Keterlibatan dan Kemampuan Teknik Personal pada Kinerja SIA dengan Pendidikan dan Pelatihan sebagai Variabel Pemoderasi. E-Jurnal Akuntansi Universitas Udayana, 20, 380408 .

Nurjaya, I. N. (2011). Landasan Teoritik Pengaturan LPD. Denpasar: Udayana University Press.

Praag, M. Van, Sluis, J. Van der, \& Witteloostuijn, A. Van. (2014). The Impact of the Locus-of- Control Personality Trait on the Earnings of Entrepreneurs visà-vis Employees. Tinbergen Institute Discussion Paper, (March).

Puspitayanti, N. K. E. D. (2015). Pengaruh Locus of Control dan Kemampuan Mengoperasikan Teknologi Informasi Terhadap Kinerja Karyawan pada PT Pegadaian (Persero) Denpasar Tahun 2015. E-Journal Undiksha, (2).

Putri Santikawati, A. A., \& Suprasto H, B. (2016). Kecerdasan Spiritual Sebagai Pemoderasi Pengaruh Locus of Control Internal dan Gaji Auditor pada Kinerja Auditor. E-Jurnal Akuntansi Universitas Udayana, 16, 557-586.

Rahayu, N. M. M. S., \& Badera, I. D. N. (2017). Pengaruh Locus of Control Internal, Motivasi Kerja, Gaya Kepemimpinan Transformasional, Komitmen Organisasi pada Kinerja Auditor. E-Jurnal Akuntansi Universitas Udayana, 19, 2378-2406.

Rahman, K. S. (2009). Analisis Pengaruh Locus of Control dan Kepercayaan terhadap Pemberdayaan Karyawan dalam Peningkatan Kinerja Karyawan.

Romney, M. B., \& Steinbart, P. J. (2014). Sistem Informasi Akuntansi (Edisi 13). Jakarta: Salemba Empat.

Rotter, J. B. (1966). Generalized Expectancies for Internal Versus External Control of Reinforcement. Psychological Monographs: General and Applied, 80(1).

Samuel, N. (2013). Impact of Accounting Information Systems on Organizational Effectiveness of Automobile Companies in Kenya, (November).

Sarastini, N. P. E., \& Suardikha, I. M. S. (2017). Pengaruh Pelatihan dan Pendidikan, Dukungan Manajemen Puncak dan Kemampuan Teknik Pemakai SIA pada Kinerja Individual. E-Jurnal Akuntansi Universitas Udayana, 20, 1476-1503.

Sari, R. M. M. (2009). Pengaruh Efektivitas Penggunaan dan Kepercayaan Terhadap Teknologi Sistem Informasi Akuntansi Terhadap Kinerja Individual pada Pasar Swalayan di Kota Denpasar. Jurnal Ilmiah Akuntansi 
Dan Bisnis, 4(1).

Suci Arini, N. M., \& Ariyanto, D. (2018). Pengaruh Locus of Control Internal, Etika Profesi dan Gaya Kepemimpinan Terhadap Kinerja Auditor. E-Jurnal Akuntansi Universitas Udayana, 23, 2230-2255.

Sugiartini, N. M., \& Dharmadiaksa, I. B. (2016). Pengaruh Efektivitas Teknologi Sistem Informasi Akuntansi pada Kinerja Individu dengan Budaya Organisasi Sebagai Pemoderasi. E-Jurnal Akuntansi Universitas Udayana, 3, 1867-1894.

Suhud, S. P., \& Rohman, A. (2015). Pengaruh Penerapan Sistem Informasi Akuntansi terhadap Kinerja Individu Pegawai Distro di Kota Bandung. Diponegoro Journal of Accounting, 4, 1-12.

Suryawan, I. K. I., \& Suaryana, I. G. N. A. (2018). Pengaruh Efektivitas Sistem Informasi Akuntansi Terhadap Kinerja Individual dengan Insentif Sebagai Variabel Pemoderasi pada LPD. E-Jurnal Akuntansi Universitas Udayana, 23, 871-897.

Turker, M. V., \& Inel, M. N. (2012). The Effect of Locus of Control Orientation on Perceived Individual Innovativeness: An Empirical Research in Turkey. Procedia - Social and Behavioral Sciences, 58, 879-888. https://doi.org/10.1016/j.sbspro.2012.09.1066

Urquia Grande, E., Perez Estebanez, R., \& Munoz Colomina, C. (2011). The Impact of Accounting Information Systems ( AIS ) on Performance Measures: Empirical Evidence in Spanish SMEs. The International Journal of Digital Accounting Research, (June 2015). https://doi.org/10.4192/15778517-v11

Wahyu Indralesmana, K., \& Suaryana, I. G. N. . (2014). Pengaruh Penerapan Sistem Informasi Akuntansi terhadap Kinerja Individu pada Usaha Kecil dan Menengah di Nusa Penida. E-Jurnal Akuntansi Universitas Udayana, 1, 1426.

Wulandari, A. A. . P. S., \& Juliarsa, G. (2017). Pengaruh Dukungan Manajemen Puncak, Keterlibatan Pengguna, Program Pelatihan Terhadap Kinerja SIA pada BPR di Kediri. E-Jurnal Akuntansi Universitas Udayana, 19, 12901319. 